\title{
Valuation of GameStop Corp. Share Price
}

\author{
Mengshan Zhang \\ Beijing National Day School, Beijing, China \\ zhangms126@126.com
}

\begin{abstract}
GameStop Corp. is a video game retailer, which has been in hard time over the outbreak of COVID-19, resulted a volatile share price in markets. This article is trying to analyze the actual value of the GameStop Corp. via two different approaches- quantitative and qualitative, in order to calculate the company's market value and reach a conclusion about the share price of GameStop, by looking at it from different aspects, such as some data from company's balance sheets, quarter and annual reports overtime, GameStop's loyalty programmes, and behavioral finance.
\end{abstract}

Keywords: Gamestop Corp; Video Game Retailer; Share.

\section{Introduction}

GameStop Corp. - an American video game retailer founded in the year 1984, headquartered in Grapevine, Texas, is an international corporate which sells multichannel video game, consumer electronics and collectibles worldwide. The company's Fortune 500 rank was exemplary 346, according to GameStop Corporate Fact Sheet, issued in 2019. In addition to the impact of digital trend which promotes the shift to online sales recent years, the outbreak of the coronavirus pandemic was another mass strike to the GameStop Corp's business. Facing hardships over time, the company announced great closures in April 2020, and at the time the share price was only $\$ 3.25$. Whereas its share price skyrocketed after Ryan Cohen, who is the former CEO of an online pet food retailer called Chewy, invested a lot into GameStop and joined the company's board as well, letting many investors believe that the company was more competitive and worth much. After that, the price of the share fluctuates from the highest $\$ 380$ to the lowest $\$ 40.65$, and results an average about $\$ 180$, which is an abnormal fluctuation compares with prices of other shares. In my opinion, GameStop is not overvalued, for the reason that it is still a company with promising future regardless of irrational investment battle between individual investors and Wall Street that have made the share price volatiles particularly.

\section{The Basic Knowledge about the Share}

\subsection{The Definition of the Share}

A share is a portion of the ownership in a corporation, also as one kind of negotiable security that is an ownership certificate, a share certificate specifically in terms of share, in which has face value and can be bought or sold at a certain price. Shares are issued by public limited companies on the purpose of financing for the corporations from shareholders in capital markets, who could gain interests and dividends as their recurrent income accordingly. Every share of a shareholder represents the ownership of a basic unit of a business' equity. In consequence, the size of each shareholder's share of ownership in a corporation is determined by how much of the company's total capital share the shareholder holds. This kind of ownership is a comprehensive right, such as attending general annual meetings, participating in decisions, voting for the board of directors and receiving interests and dividends, etc. Meanwhile, shareholders as the investors of the corporations, are supposed to assume the risks of investment and failure of the business, with which their investment of purchasing shares may be lost. There are three main types of shares classified in accordance with shareholder's rights: ordinary share, preferred share and reserved share. 


\subsection{Capital Market}

Capital markets are important parts of financial markets, where transaction could happen between suppliers of capital and individuals or institutions who demand for it. Transactional efficiency can be improved because of capital markets as platforms, enable fund exchanges easily and efficiently. Capital markets consist of primary and secondary market. Stock market is one of the most common capital markets.

\section{Share Valuation of GameStop Corp.}

\subsection{Quantitative Analysis}

\subsubsection{Balance Sheets, Quarter and Annual Reports}

The company's performance in first and second quarters of 2021 was quite striking.

According "GameStop Releases First Quarter 2021 Financial Results": The company's 'net sales increased $25.1 \%$ to $\$ 1.277$ billion, compared to $\$ 1.021$ billion in the fiscal 2020 first quarter, overcoming a nearly $12 \%$ reduction in the Company's global store base due to strategic dedensification efforts, and continued store closures across Europe due to the COVID-19 pandemic'. The good performance. About capital structure and liquidity update, as of May 1, 2021, GameStop Corp. had $\$ 770.8$ million in cash and restricted cash, which is an increase that compared to $\$ 583.9$ million in cash and restricted cash in the prior year. The Company had no borrowings under its assetbased revolving credit facility and no long-term debt. This shows a positive debt situation, that the company's cash was still quite sufficient, and the liquidity was quite high, showing the ability of overcoming some emergencies may happen. However, the company's gross margin was $25.9 \%$, presented a decline of 180 basis points compared to the fiscal 2020 first quarter. The increase of net sales, high liquidity and positive debt situation will promote GME's price, while the declining gross margin will reduce the share price to an extent.

On April 26, 2021, the Company announced it raised approximately $\$ 551.7$ million in net proceeds through the issuance of 3.5 million shares of common stock under its "at-the-market" equity offering program, resulting in total shares outstanding of approximately 71.9 million. The Company has used and intends to continue using net proceeds to accelerate GameStop's transformation as well as for general corporate purposes and further strengthening the balance sheet.

In the second quarter, GameStop generated net sales of $\$ 1.183$ billion, compared to $\$ 942$ million in the prior year's second quarter, which is a positive trend. The company ended the period with no long-term debt, other than a $\$ 47.5$ million low-interest loan associated with the French government's pandemic response. The second quarter report is shown that GameStop was actively operated its business as well as speeded up its transformation to the online selling business under the condition that the recovering pandemic situation. It Invested in long-term growth initiatives that include expanding the Company's product catalog, enhancing its fulfillment network capabilities and technology, and adding talent across the organization. The company also expand its business into a wider area: it entered into a lease of a new 530,000 square foot fulfillment center in Reno, Nevada, positioning the Company's fulfillment network to span both coasts of the continental U.S. It also entered into a lease of a new customer care center in Pembroke Pines, Florida and started building out U.S.-based customer care operations. An active practice of transforming is a promotion for the market price.

\subsubsection{Price to Book Value Calculation}

According the calculation method of Price to Book Value, and based on relatively reliable data online, I've calculated the Price to Book Value for GameStop, CeX, and Game Digital. P-t-B of Game Digital is lower than GameStop, while both of the two values are much greater than 1, which is a standard to evaluate whether the company's share price is overvalued. In the perspective of Price to Book Value, the current share price of GameStop is quite overvalued. 
Table 1. Price to Book Value Calculation

\begin{tabular}{|lllll|}
\hline & GameStop & CeX & Game Digital \\
\hline Total Assets & $2.5 \mathrm{~b}$ & $1.1 \mathrm{M}$ & $199.4 \mathrm{~m}$ \\
\hline Total Liabilities & $2.0 \mathrm{~b}$ & $997.6 \mathrm{k}$ & $100.9 \mathrm{~m}$ \\
\hline Book Value & $0.5 \mathrm{~b}$ & 102400 & $98.5 \mathrm{~m}$ \\
\hline Share outstanding & $617.1 \mathrm{~m}$ & $102.7 \mathrm{k}$ & $98.5 \mathrm{~m}$ \\
\hline Book Value per Share & 0.81 & 1 & 1 \\
\hline Share Price & 170 & $\mathrm{~N} / \mathrm{A}$ & 30 \\
\hline Price to Book Value & 209.8 & $\mathrm{~N} / \mathrm{A}$ & 30 \\
\hline
\end{tabular}

\subsection{Qualitative Analysis}

\subsubsection{Loyalty Programs}

The company operates loyalty programs, also known as PowerUp Rewards, in countries they operate video game stores respectively. The PowerUp Rewards, had about 47.1 million members up to January 30, 2021, of which the paying members who have purchased or traded at GameStop counted for 15.2 million. The loyalty programs generally provide consumers a continuously motivation to consume at GameStop. The paid memberships can obtain subscription to Game Informer magazine and additional discounts and benefits in stores and e-commerce properties. These actions can efficiently increase the consumer loyalty and develop company's goodwill to an extent.

\subsubsection{Trademarks and Service Marks}

GameStop Corp. has a quantity of trademarks and servicemarks registered with the U.S. Patent and Trademark Office, including "GameStop ${ }^{\circledR}$, ," "Game Informer ${ }^{\circledR}$," "EB Games ${ }^{\circledR}$, " "Electronics Boutique $^{\circledR}$," "ThinkGeek ${ }^{\circledR}$," "Zing Pop Culture ${ }^{\circledR}$," "Power to the Players ${ }^{\circledR ”}$ and "PowerUp Rewards ${ }^{\circledR}$, A $\quad$ great number of trademarks and servicemarks, are under registration, including "Micromania ${ }^{\mathrm{TM}}$, ,. The brand's goodwill has a strong effects in the video game market.

\subsubsection{Video Game Industry}

Evaluating the whole video game industry brings some new perspectives to better understand what circumstance GameStop is situated in. In accordance with GameStop's annual report, there is no doubt that video game industry, as a cyclical business affected by the introduction of next-generation consoles, for which the demand for existing products or pre-owned business will be negatively impacted. Investors' expectations of video game industry will be decreased; thus, the share price will easily be undervalued.

\subsubsection{Behavioral Aspects}

The effects of behavioral aspects are also vital. Behavioral finance, to define it, is the study of how psychology influences the behaviour of investors. There are some main traits of behavioral finance: first, investors are treated as "normal" not "rational"; second, they actually have limits to their selfcontrol; third, investors are influenced by their own biases; fourth, investors make cognitive errors that can lead to wrong decisions. For example, the increase of the share price after the announcement of the new director of board indicates the fact that the market is quite efficiency. Nevertheless, the boom of share price after a long-term depression and share prices that are more volatile than normal even at this time both reveals the existences of many irrational individual investors. That is, the market inefficiency and the irrational investors make the share price of GameStop more volatile that it is easier to be undervalued. 


\section{Summary}

GameStop is not overvalued and the company still has a lot of room to grow. From the quantitative aspect, the company's amount of sale remains a high standard, the liquidity and liabilities are of good states, though gross profit still has space to improve. From the qualitative aspect, the company keeps altering its strategy to deal with the changing and unexpected market environments, strengthens its management teams, and it is attempting to transform from a traditional offline video game retailer to a company combined with the advantages of online selling and physical retailing.

\section{References}

[1] Information on: https://investor.gamestop.com/static-files/a07563a1-de5d-43d0-bb11-d6bf d309 dacd.

[2] Information on: https:// www. sec.gov/Archives/edgar/data/1326380/0 000921895 20001510/ ex1todfan 14a12166002_051920.pdf.

[3] Information on: https://plaintips.com/stores-like-gamestop.

[4] Information on: https://financesonline.com/amazon-statistics/.

[5] Information on: https://www.companieshistory.com/best-buy/\#: : text= Best\% 20Buy\% 20Co.\% 2C\%20 Inc. $\% 20$ is $\% 20 \mathrm{a} \% 20$ multinational\%20retailer\%2C,operates\%20through\%20two\%20business\%20segme nts\%3A\%20Domestic\%20and\%20International.

[6] Information on: https://www.fool.com/investing/2021/04/06/is-gamestop-the-next-blockbuster-amazonor-best-bu/\#: : text= Amazon.com\% 20was $\% 20$ and $\% 20$ continues $\% 2$ 0to\%20b e $\% 20 \mathrm{a} \% 20$ leading, first $\%$ 20 when $\% 20$ it $\% 27 \mathrm{~s} \% 20$ time $\% 20$ to $\% 20$ shop $\% 20$ for $\% 20$ anything.

[7] Information on: https://digital.hbs.edu/platform-rctom/submission/disruption-of-video-game-retailers/.

[8] Information on: https://www.statista.com/topics/868/video-games/.

[9] Information on: https://investor.gamestop.com/news-releases/news-release-details/gamestop-releasesfirst- quarter-2021-financial-results.

[10] Information on: https://investor.gamestop.com/news-releases/news-release-details/gamestop-reportsfinancial-results-q2-2021.

[11] Information on: https://corporatefinanceinstitute.com/resources/knowledge/trading-investing/behavioralfinance/.

[12] Information on: https://craft.co/gamestop/metrics\#balance-sheet.

[13] Information on: https://www.dfcint.com/dossier/video-game-industry-segments-games-as-a-serviceversus-traditional-games/\#: :text=Pay-to-play\% 20is\% 20what $\% 20$ most $\% 20$ people $\% 20$ think $\%$ 20of\% 20as, need $\% 20$ to $\% 20$ package $\% 20$ the $\% 20$ game $\% 20$ in $\% 20 \mathrm{a} \% 20$ box.

[14] Information on: https://baike.baidu.com/item/\%E8\%82\%A1\%E7\%A5\%A8/22647?fr=aladdin\#6.

[15] Information on: https:// baike. baidu. com/item/\% E8\% B5\%84\% E6\%9C\% AC\%E5\% B8\% 82\% E5\% 9C\% BA/969? fr=Aladdin.

[16] Information on: https://www.investopedia.com/terms/c/capitalmarkets.asp. 